\title{
INTERVENSI TERAPI AKUPRESURE (TITIK L14) PADA NYERI PERSALINAN KALA I AKTIF
}

\author{
Retty Nirmala Santiasari*., Ethycasari*., Andri Dwi Saputri * \\ *STIKes William Booth Surabaya, Jl.Cimanuk No.20 Surabaya \\ E-mail: rettynirmala@gmail.com
}

\begin{abstract}
ABSTRAK
Nyeri merupakan kondisi fisiologis dari proses persalinan dan melahirkan. Nyeri pada fase aktif dipengaruhi oleh adanya proses dilatasi serviks, segmen bawah uterus dan distensi korpus uteri. Tindakan non farmakologi dapat dilakukan untuk mengurangi rasa nyeri persalinan yaitu dengan terapi akupresur titik L14. Tujuan studi kasus ini adalah melaksanakan asuhan keperawatan pada nyeri persalinan kala I aktif di ruang VK RSUD Bangil Kabupaten Pasuruan. Metode ini adalah study kasus dengan sampel 2 pasien dengan persalinan kala I aktif yang dirawat selama 3 hari. Sehingga study kasus didapatkan diagnosa prioritas adalah nyeri akut berhubungan dengan kontraksi uterus. Implementasi yang dilakukan pada kedua pasien adalah mengobservasi reaksi ketidaknyamanan non-verbal dari raut wajah atau tingkah laku, mengontrol lingkungan pasien dan suhu ruangan, melakukan pengkajian nyeri, memberikan terapi nonfarmakologis yaitu terapi akupresure pada titik L14, mengajarkan tehnik akupresur titik L14. Terapi akupresur titik L14 dapat mengatasi nyeri persalinan pada fase aktif dengan memberikan tekanan pada suatu titik akupresur di titik L14 yaitu diantara tulang metacarpal pertama dan kedua pada bagian distal dengan Gerakan memutar. Gerakan ini merupakan terapi akupresur yang mampu menurunkan rasa nyeri persalinan pada fase aktif. Evaluasi pada kasus pasien 1 dan 2 dengan masalah keperawatan nyeri akut ditandai dengan pasien tidak mengeluh nyeri. Hasil menunjukkan keefektifan implementasi pada kedua pasien mengalami perbaikan kondisi dan masalah keperawatan nyeri kronis pada kedua pasien teratasi.
\end{abstract}

Kata Kunci: Terapi akupresur titik L14, Nyeri persalinan, Fase aktif

\begin{abstract}
Pain is a physiological condition of labor and delivery. Pain active phase is influenced by the dilatation of the cervix, lower uterine segment and distension of the uterine body. Non Pharmacological used to reduce the pain of labor is acupressure therapy point L14. The purpose of this case study was to carry out nursing care for the first stage of active labor pain in the VK room at Bangil Hospital, Pasuruan. This method is a case study with a sample of 2 patients with active stage I labor who were treated for 3 days. So that the case study found the priority diagnosis is acute pain associated with uterine contractions. The implementation carried out in both patients was observing non-verbal discomfort reactions from facial expressions or behavior, controlling the patient's environment and room temperature, conducting pain assessments, providing non-pharmacological therapy, namely acupressure therapy at
\end{abstract}


point L14, teaching acupressure techniques at point L14. Acupressure L14 point therapy can overcome labor pain in the active phase by applying pressure to an acupressure point at point L14, which is between the first and second metacarpal bones distally with a circular motion. This movement is an acupressure therapy that can reduce labor pain in the active phase. Evaluation in cases of patients 1 and 2 with acute pain nursing problems was characterized by the patient not complaining of pain. The results showed that the effectiveness of the implementation in both patients had improved conditions and the problem of chronic pain nursing in both patients was resolved.

Keywords: L14 Point Acupressure Therapy, Labor Pain, active phase.

\section{PENDAHULUAN}

Persalinan sebagai proses alami

yang dialami oleh ibu bersalin dan berlangsung secara fisiologis dalam kehidupan. Persalinan dapat diartikan sebagai proses keluarnya janin, plasenta, dan membran dari dalam rahim melalui jalan lahir (Rohani, 2011). Respon fisiologis dari persalinan adalah munculnya kontraksi rahim yang menimbulkan rasa nyeri dan ketidaknyamanan bagi ibu saat menghadapi persalinan (Manurung, 2011). Keadaan ini mulai timbul pada kala 1 yaitu di fase laten dan fase aktif. Pada kala I persalinan, kontraksi uterus menyebabkan dilatasi serviks dan mendorong janin menuju jalan lahir. Kontraksi uterus yang dialami menimbulkan rasa nyeri (Walyani dkk, 2016). Nyeri pada fase aktif merupakan nyeri fisiologis yang terjadi dalam waktu yang lebih lama, untuk itu perlu penanganan mengatasi nyeri pada kala I persalinan. Apabila nyeri dalam persalinan tidak diatasi akan memunculkan masalah tidak hanya menyakitkan bagi ibu akan tetapi juga mengancam bagi janinnya.

Menurut WHO (World Health Organization) pada tahun 2015, sebanyak 99\% kematian ibu akibat masalah persalinan terjadi di negaranegara berkembang. Angka kematian ibu dan bayi baru lahir di Jawa Timur (Jatim) masih tinggi, meskipun angkanya masih jauh dibandingkan dengan angka tingkat nasional. Tahun 2017 angka kematian ibu dan bayi melahirkan sebanyak 529 dan tahun 2018 hingga September 
sebanyak 431 orang (Dinkes Propinsi Jawa Timur, 2018).

Berdasarkan permasalahan dan dampak yang ditimbulkan maka dibutuhkan manajemen nyeri untuk menurunkan rasa nyeri yang di timbulkan di antaranya yaitu prosedur farmakologi. Metode Farmakologi dianggap tindakan yang mempunyai kerugian yaitu lebih mahal dan memberikan efek samping, prosedur farmakologi yaitu dengan cara pemberian analgesic yang bertujuan untuk mengurangi atau menghilangkan rasa nyeri, sehingga perlu kombinasi tekhnik non-farmakologi agar sensasi nyeri dapat ditoleransi dan berkurang (Budiarti, 2011). Tindakan non farmakologi merupakan Tindakan yang tidak berpotensi menimbulkan efek samping berbahaya dan dapat meningkatkan rasa nyaman selama proses persalinan, karena dengan memberikan rasa nyaman pada ibu maka dapat mengontrol perasaan dan kekuatan ibu dalam menghadapi persalinan (Danuatmaja, 2014). Terapi non faramakologi yang dapat digunakan untuk mengatasi nyeri persalinan diantaranya, manajemen nyeri. Penelitian yang dilakukan oleh Retty Nirmala S, dkk (2018) menjelaskan bahwa pijat effluerange dapat mengurangi rasa nyeri pada nyeri persalinan.

Pada penelitian ini, peneliti menggunakan salah satu terapi nonfarmakologi yaitu terapi akupresur titik L14. Akupresur adalah tindakan yang sangat sederhana, mudah dilakukan, memiliki efek samping yang minimal, dan aplikasi prinsip healingtouch.

Terapi akupresur titik L14 adalah tindakan yang dapat dilakukan juga untuk membantu mengelola emosi dan membantu dalam mengembangjkan kecerdasan emosional. Terapi ini dilakukan dengan cara menggenggam ibu jari pasien, kemudian ibu jari terapi memberikan penekanan pada titik L14 yang terletak diantara tulang metacarpal pertama dan kedua bagian distal dengan Gerakan memutar. Terapi ini diberikan saat terjadinya puncak kontraksi pada fase aktif. Terapi akupresur dapat merangsang pengeluaran endorphin dalam darah, yang mampu mengontrol 
terjadinya nyeri persalinan Terapi ini juga dapat mengeluarkan hormon oksitosin dari kelenjar hipofisis, yang

secara langsung merangsang kontraksi uterus (Budiarti, 2011). Menurut hasil penelitian Andri Dwi S (2019), didapatkan nilai $p 0.00(p<0.05)$ yang mempunyai arti bahwa terdapat perbedaan yang bermakna pada terapi akupresure terhadap nyeri persalinan sebelum dan sesudah diberikan intervensi.

Selama penulis menjalankan praktek profesi ners di ruang VK selama 1 minggu ditemukan semua ibu yang akan melahirkan secara normal maupun sc mengalami masalah nyeri akut pada persalinan kala I fase aktif, yaitu sebanyak 20 pasien yang dirawat. Hal ini dapat menunjukkan bahwa masalah nyeri akut pada persalinan merupakan salah satu masalah yang paling sering dijumpai, khususnya pada pasien dengan persalinan kala I fase aktif. Sehingga peneliti tertarik untuk meneliti penurunan nyeri melalui tekhnik nonfarmakologi terapi akupresur titik L14 pada pasien dengan nyeri persalinan kala I aktif di ruang
VK RSUD Bangil Kabupaten Pasuruan.

\section{METODE}

Desain yang digunakan pada penelitian ini adalah studi kasus, yaitu studi yang mengeksplorasi suatu fenomena dengan batasan terperinci, pengambilan data yang mendalam dan menyertakan berbagai sumber informasi (Mudjia Rahardjo, 2017). Tujuan penelitian studi kasus ini untuk mengeksplorasi asuhan keperawatan pada ibu bersalin kala I aktif dengan masalah keperawatan nyeri akut di ruang VK dengan menggunakan instrmen skala nyeri Numeric Rating scale (NRS). Instrumen NRS digunakan untuk menilai skala nyeri yang dirasakan pasien dengan menggunakan angka dalam menggambarkan rentang intensitas nyeri dengan kriteria nilai 0 tidak nyeri, 1-3 nyeri ringan, 4-6 nyeri sedang, dan 
7-10 nyeri berat. Lama waktu perawatan pasien yaitu 3 hari. Pengumpulan data dilakukan dengan observasi dan pemeriksaan fisik. Disamping integritas penelitian (instrumen utama menggunakan lembar observasi), uji keabsahan data dilakukan dengan menambahkan waktu proses tindakan dan sumber informasi tambahan menggunakan tiga sumber data yaitu pasien, perawat dan keluarga pasien yang berkaitan dengan masalah yang diteliti. Pada penelitian ini, peneliti menegakkan pada masalah etika penelitian dimana lembar persetujuan diberikan sebelum penelitian dilaksanakan kepada objek yang akan diteliti maka harus menandatangani lembar persetujuan,

\section{HASIL}

Hasil penelitian menunjukkan bahwa pada kedua responden berusia dewasa awal dalam rentang usia 20-35 tahun dengan kehamilan multigravida. Pasien pertama didapatkan hasil pengkajian nyeri PQRST (P: nyeri persalinan kala I, Q: kencang-kencang, R: perut bagian bawah, S: 9 dari 0-10 NRS, T: 4x10' lama 37'). Pada pasien kedua didapatkan hasil pengkajian nyeri PQRST (P: nyeri persalinan kala I, Q: kencang-kencang, R: perut bagian bawah, S: 8 dari 0-10 NRS, T: 3x10' lama 36"). Pasien sama-sama mengalami nyeri akut dikarenakan sesuai dengan gejala yang dirasakan pada pasien dengan persalinan kala I aktif yaitu sara nyeri yang dimulai dari bagian bawah perut, rasa sakit seperti kencang - kencang, kejadian ini diakibatkan ketika otot-otot rahim berkontraksi untuk mendorong bayi keluar dari dalam rahim ibu. 


\section{PEMBAHASAN}

Pengkajian pada pasien pertama

dan kedua didapatkan keadaan umum pasien terlihat lemas, meringis

kesakitan, gelisah, suara bergetar,

pasien mengatakan perut terasa

kencang-kencang disertai nyeri pada

bagian bawah dengan skala nyeri

pasien pertama 9 dan pasien kedua 8 .

Menurut Jenny (2013) persalinan akan

berlangsung apabila terjadi kontraksi

persalinan yang dating lebih kuat

sering, dan teratur yang menimbulkan

rasa nyeri. Dari penjabaran diatas pada

kasus pasien 1 dan pasien 2 terdapat

perbedaan pada skala nyeri yang

dialami pasien pada pasien 1 skala nyeri

9 dan pasien 2 skala nyeri, hal ini

disebabkan pada pasien pertama belum

mempunyai pengalaman nyeri

persalinan sebelumnya dikarenakan

pada saat kehamilan pertama pasien

mengalami abortus pada usia

kehaliman 16 minggu, sedangkan pada pasien kedua pernah mengalami

pengalaman nyeri persalinan

sebelumnya.

Berdasarkan data diagnosa

keperawatan yang ditemukan pada pasien pertama dan kedua yaitu nyeri akut berhubungan dengan kontraksi pada uterus dan ansietas berhubungan dengan krisis situasional. Secara teori diagnosa keperawatan yang muncul adalah nyeri akut berhubungan dengan kontraksi uterus, distensi abdomen, luka episiotomi, keletihan berhubungan dengan kontraksi, ansietas berhubungan dengan krisis situasional, hipovolemi berhubungan dengan atonia uteri, gangguan integritas kulit berhubungan dengan episiotomy, risiko syok berhubungan dengan perdarahan, risiko cedera pada janin berhubungan dengan hipoksia janin, resiko infeksi berhubungan dengan trauma jaringan. 
Pada kasus pasien pertama dan kedua tidak ditemukan diagnose keletihan dikarenakan tidak ditemukan tanda gelaja keletihan yaitu pasien tidak menunjukkan adanya keluhan lelah. Pasien tidak ditemukan masalah hipovolemi karena pada pasien tidak terlihat tanda gejala hipovolemi yaitu kehilangan banyak cairan, membrane mukosa lembab, turgor baik elastis, tidak ditemukan keluhan haus, tanda tanda vital dalam batas normal. Pada kasus nyata tidak ditemukan diagnosa keperawatan resiko syok dikarenakan data tidak mendukung, karakteristik resiko syok hipovolemi yaitu terdapat tanda-tanda seperti penurunan tekanan darah, dan frekuensi nadi, penurunan turgor kulit, penurunan haluaran urin, membran mukosa kering, kulit kering, peningkatan suhu tubuh, dan kelemahan. Hal ini tidak terdapat pada pasien.
Rencana asuhan keperawatan dalam pemberian terapi akupresur titik L14. Tindakan terapi akupresure pada titik L14 dilakukan dengan beberapa tahap yaitu, tahap persiapan; mempersiapkan ruangan, mengucapkan salam dan memperkenalkan diri dengan pasien, menjelaskan maksud dan tujuan dilaksakan akupresure pada pasien, menanyakan pada pasien mengenai kesediaan mengikuti terapi akupresure. Pelaksanaan; cuci tangan sebelum melakukan tindakan, mengatur posisi pasien, mengecek tidak ada luka atau bengkak pada tangan yang akan dilakukan penekanan, mengkaji tingkat nyeri, melakukan penekanan pada titik akupresur pada saat pasien mencapai puncak kontraksi, baik ditangan kanan atau kiri. cara melakukan tehnik akupresur pada tangan; berikan tekanan lembut pada titik 14 yaitu pada antara tulang metacarpal pertama dan kedua 
bagian distal dengan gerakan memutar, hentikan penekanan jika kontraksi mulai reda, berikan jeda sampai kontraksi berikutnya. Terminasi; setelah terapi selesai, perawat menanyakan bagaimana perasaan pasien setelah melakukan terapi akupresur.

Implementasi pada pasien pertama dan kedua tidak terdapat kesenjangan. Pada implementasi pasien 1 dan pasien 2 terfokus menggunakan tindakan terapi akupresur titik L14, Tindakan terapi akupresure pada titik L14 dilakukan dengan beberapa tahap yaitu, tahap persiapan; mempersiapkan ruangan, mengucapkan salam dan memperkenalkan diri dengan pasien, menjelaskan maksud dan tujuan dilaksakan akupresure pada pasien, menanyakan pada pasien mengenai kesediaan mengikuti terapi akupresure. Pelaksanaan; cuci tangan sebelum melakukan tindakan, mengatur posisi pasien, mengecek tidak ada luka atau bengkak pada tangan yang akan dilakukan penekanan, mengkaji tingkat nyeri, melakukan penekanan pada titik akupresur pada saat pasien mencapai puncak kontraksi, baik ditangan kanan atau kiri. cara melakukan tehnik akupresur pada tangan; berikan tekanan lembut pada titik 14 yaitu pada antara tulang metacarpal pertama dan kedua bagian distal dengan gerakan memutar, hentikan penekanan jika kontraksi mulai reda, berikan jeda sampai kontraksi berikutnya. Terminasi; setelah terapi selesai, perawat menanyakan bagaimana perasaan pasien setelah melakukan terapi akupresur. Intervensi terapi akupresur pada diagnose nyeri merupakan salah satu intervensi tekhnik nonfarmakologi yaitu tekhnik distraksi. Menurut hasil penelitian Okta Vitriani (2017) dalam 
jurnalnya yang berjudul "Pengaruh

Terapi Akupresur Terhadap Intensitas

Nyeri Persalinan Pada Ibu Bersalin

Kala I Aktif di Puskesmas Sedinginan

Tahun 2017" terapi akupresur memiliki

pengaruh terhadap tingkat nyeri pada pasien persalinan kala I aktif.

Evaluasi keperawatan pada pasien persalinan kala I aktif dengan masalah keperawatan nyeri akut setelah dilakukan tindakan keperawatan selama 3 hari pada pasien pertama dan kedua didapatkan masalah teratasi ditandai dengan pasien mengatakan sudah tidak merasakan nyeri, wajah pasien segar, skala nyeri pada pasien 1 menurun menjadi 6 dan pasien 2 menjadi 5 dan dokter advis pasien diijinkan pulang.

Maka dapat disimpulkan bahwa terapi akupresur titik L14 dapat menurunkan skala nyeri pada masalah nyeri akut persalinan kala I aktif. Hasil penelitian ini dapat dijadikan pertimbangan dasar atau bahan data penelitian selanjutnya dengan cara dan teknik yang berbeda serta faktor-faktor lain yang berhubungan dengan nyeri akut pada persalinan kala I aktif.

\section{KESIMPULAN}

Dari hasil yang didapatkan setelah penulis memberikan intervensi terapi akupresur titik L14 pada masalah nyeri akut persalinan kala I aktif didapatkan pasie pertama mengalami penurunan skala nyeri dari 9 menjadi skala nyeri 6, dan pasien kedua mengalami penurunan skala nyeri dari 8 menjadi skala nyeri 5. Maka dapat disimpulkan bahwa terapi akupresur titik L14 dapat menurunkan skala nyeri dan meningkatkan toleransi terhadap nyeri pada masalah nyeri akut persalinan kala I aktif. 


\section{REFERENSI}

Budiarti, D. 2011. Hubungan akupresur dengan tingkat nyeri dan lama persalinan di garut. Universitas Indonesia Depok.

Danuatmaja, B. 2014. Persalinan Normal Tanpa Rasa Sakit. Jakarta : Puspa Swara.

Dinas Kesehatan Provinsi Jawa Timur. Data Dinas Kesehatan Provinsi Jawa Timur 2018. Dinas

Kesehatan Provinsi Jawa Timur: Surabaya

Jenny J. S. Sondakh. 2013. Asuhan Kebidanan Persalinan \& Bayi Baru Lahir. Jakarta: Erlangga

Manurung, Santa. 2011. Keperawatan Profesional, Jakarta: Tim

Rahardjo, Mudjia. 2017. Studi Kasus salam Penelitian Kualitatif: Konsep dan Prosedurnya.

Retty Nirmala Santiasari, Detty S. N., dan Wiwin L. 2018.

Effectiveness of Effleurage and Counter-Pressure Massages in Reducing Labor Pain. Health Notions, Vol.2

Rohani, Saswita R, Marisah. 2011. Asuhan Kebidanan Pada Masa Persalinan. Jakarta: Salemba Medika.
Saputri, Andri D.2019.Pengaruh Terapi Relaksasi Akupresur (Genggam Jari) Terhadap Nyeri Persalinan Kala I Aktif di Bidan Praktek Mandiri Afah Fahmi Surabaya. Skripsi. STIKes Wiliam Booth Surabaya.

Walyani Elisabeth Siwi. 2017. Asuhan Kebidanan Pada Kehamilan. 2nd ed. Yogyakarta: PT. Pustaka Bau 